\title{
2 \\ Well-Intentioned White People and Other Problems with Liberalism
}

Chapter 1 located the notion of the complicit subject within the psychological humanities and the subject of psychology. It argued that the Western notion of human being, which informs the subject of psychology, is based on a binary structure that reflects and reproduces oppressive power dynamics. This binary relationship encodes and enables psychic and systemic power relations (since the two are complicit in each other). The power dynamics enabled by binary logic work through refusing the complicit nature of human being in favor of a relationship between self and other that needs, among other things, a liberal subject formation.

A liberal subject is one who requires sameness in his relationships, who cannot truly tolerate difference. He is born from the Enlightenment's valorization of the rational, self-enclosed individual, a mind who can and should know and control himself-and thus, a subject fundamentally alienated from the capacity to handle encounters with the otherness that is central to what it means to be human. He grew in the soil of capitalism, and the gender and race binaries from which it profited. He eventually fragmented under neoliberalism, as the pressures of capitalism in a globalized economy reached ever further into systems and their subjects. 
This chapter provides more detail about the subject of liberalism and its relationship to relations of power. It tracks the move from liberalism to neoliberalism as political, economic and cultural structures of power that have affected the nature of the Western (and Westernized) subject of psychology. It also summarizes the argument that the psy disciplines, and therefore the subject of psychology, are fundamentally implicated in techniques of liberal subjectification. As a consequence, the model of human being on which psychotherapy is built is limited by this history and its effects. Thinking complicitously opens clinicians up to the full potential of intersubjective co-creation with clients, a point which will be fully explored in the final chapter. This entails a commitment to move away from liberal individualism and its ideas about autonomy. It also entails an awareness of the effects of neoliberalism on twenty-first century subjects, which is explored in more detail in Chap. 5.

\section{Liberalism}

Before coronavirus, before the racial justice protests sparked by the lynching of George Floyd, before the ugly contentions of the 2020 presidential elections, but right in the middle of the maelstrom of Trumpism, I became a U.S. citizen. My citizenship ceremony took place during the government shutdown at the beginning of 2019, which was caused by a battle over the symbol of a pointless, expensive, destructive wall on the southern American border. Outside the Orpheum Theatre in Oakland, landfill in the shape of little plastic American flags made in China were being sold by a range of people, all of whom were not white. Inside the Orpheum, the very nice staff from the Department of Homeland Security, San Francisco branch, went out of their way to let us know that the majority of the 1000 or so people qualifying for citizenship that day were from Mexico (and then China, and then India). They told us that we were the best of America, and most welcome here. Their political subversion in the context of the Trumpocalypse was clear, and I appreciated it.

They also got a choir of nice elderly people to sing us, "This Land Is Your Land," among other examples of musical Americana. Apparently being inducted into Americanness means being invited to collude with 
historical amnesia about whose land, exactly, we are on. They showed us a carefully curated slide show of images of immigrants of many ethnicities and colors coming to America over the years. They told us immigrants built America, again indulging in national amnesia. I felt deeply uncomfortable participating in the celebration of nationalism with these necessary omissions. I also felt the privilege of being granted citizenship at a time when some families were being torn apart for trying to get in to this country. I felt very appreciative of being in a country which allowed government representatives to speak out against the government, and appreciative of how they asserted that America is the people in it, not the people in charge. This whole ambivalent event says something, I think, about the liberalism that has built this country and allowed it to continue selling parts of itself for celebrating, while pretending other parts do not exist.

The whitewashed American fantasy is that anyone can achieve anything here, in this land of opportunity, if he just works hard enough. Each person, this fantasy goes, is free to do his best, and entitled by god, law and ethics to the right to be his individual self, make his individual decisions and own his individual stuff. The messy American truth is much murkier, since not everyone has equal access to the opportunities to get ahead. It is also complicated by the larger human and ecological truth that we do not, in fact, each stand alone, that we are implicated in each other's choices whether we like it or not. The exalted ideal of the individual and his rights - the liberal subject, entitled to his land, his guns, his family, his freedom-is not a god-given truth but a construct formed at the cost of a host of others. It also fundamentally disallows the concept of human complicity. Despite even its best intentions, this fierce liberal individualism is profoundly responsible for helping to structure a deeply unequal society, a way of thinking about human being that is inimical to human being (see Davis, 2020). It is part and parcel of systems of oppression, even as it also is deeply committed to discourses of truth, freedom and human happiness.

Liberalism began as both a political and an economic philosophy. It has come to encode the politics of socioeconomic policy as morality. As a political system of thought, it originated in Europe, possibly as far back as the Magna Carta in the thirteenth century, which attempted to limit 
the monarch's divine right over the individual liberties of the landed gentry. It has thus always been classed. It has come, broadly, to stand for individual rights to, among other things, free will to choose, bodily autonomy and land ownership, none of which can actually be asserted by most individuals in most of the world. Despite what it thinks of itself, there are very real limits to liberalism's claims to universality, to its belief that it encodes values of general human dignity, truth and justice.

Guyatt (2016) has argued that from America's inception, wellintentioned white people recognized that America's founding principleall men are created equal —was incompatible with genocide and slavery. But they could not accept the differences represented by Native Americans and Africans as equal to their own culture and values. In perhaps the most pernicious blind spot of Western culture, one which arguably builds on a philosophical inability to come to reasonable terms with sexual difference, these early liberal white Americans recognized the humanity of their others but not their innate equality. That could only come if and when They became more like Us. This is the problem with liberalism. Its message is ultimately about the centrality of the whiteness, maleness and classness that birthed it. It looks at others and measures their worth in their willingness to become like itself. It is also terribly, terribly wellintentioned, since it is so obviously the best of what it means to be human that wanting to assimilate others into itself is only a gift, a measure of its generosity. It is a benign Borg. It is bewildered by opposition or resentment from those it wants to help.

It also normalizes the idea that selfhood and ownership are coconstituting. Liberalism, in its insistence on the rights of the individual, encodes capitalist assumptions about the relationship between property and personhood. Part of being a person is the right to own stuff. This inevitably translates into maneuvers for economic and social power, to which other meanings of humanity become subject.

My first understanding of liberalism is through a South African lens. The terms of the debate are different there (see Distiller, 2005). There was a Liberal Party for a while, but it died in the face of apartheid (Rich, 1997). Stephen Bantu Biko (1978), a visionary writer and anti-apartheid activist beaten to death by the police in 1977, made it impossible for any progressive South African to be proud of the epithet. A white liberal, 
according to Biko, was someone who spoke for black people, who did not recognize their agency. White liberals were (are) products and beneficiaries of racism who were (are) unable to see their own location in the system and how their well-intentioned actions perpetuate injustice, specifically, for Biko, racial injustice.

Post apartheid, liberalism and liberal values continued to be highly contested and racialized (Husemeyer, 1997; Johnson \& Welsh, 1998). This is unsurprising, given the class and race tensions the ideology carries in postcolonial times. Liberal ideals fed colonial discourse, in part by circulating a veneer of morality which stitched individual rights (in formations which benefitted colonizers, like the right to own property, without the acknowledgment of the ownership rights of the people who had been there first) to democracy and its institutions. In so doing, it bestowed the state with commitments to dignity and freedom that were, in reality, extremely partial (Mehta, 1999).

As Brown (1995, p. 17) points out, the modern Western state is dependent upon liberalism to authorize its apparently "self-generating" functions: "social repairs, economic problem solving, and the management of a mass population." Liberal ideals helped to create the idea of the modern nation state, whose job it is to manage and protect the rights of the apparently free individual members of said nation. But the state, and the liberal ideas it relies upon and helps to produce, creates the individuals it goes on to protect. And this state, these individuals and the rights to which they are entitled by the law created by the state in the name of its individuals, these things have a very specific history. Perry (2018) has tracked the mutual development of modern patriarchy in the Enlightenment via slavery, colonialism and specific uses of juridical power. This emerging law conflated manhood (meaning legally endorsed, raced, personhood) and the right to property, to create subjects and objects of government.

Perry (2018) shows how economic liberalism, which she tracks to the early expansion of European Empire at the start of the Enlightenment, and which was enriched by the early slave trade, was also a political and a philosophical system. The entire enterprise was enabled by a use of the law to grant ownership rights to those considered people. Thus, economic liberalism is inextricable from "specifically, the doctrine of personhood [which] entails a system whereby the subject before the state or the law 
was made into either a patriarch, his liege (woman), or someone outside legal recognition, whether slaves or... 'savages' but whom we can also term 'nonpersons' in the juridical sense" (Perry, 2018, p. 21). She shows how the legal personhood granted the gendered, raced, classed liberal subject of emerging modernity was based on the exclusion of those not afforded the legal recognition of their personhood. The right to selfdetermination, legally and physically, continues to rely on having access to legally recognized personhood and what Perry calls "political recognition."

Rose (1998) has further detailed how individuality and governmentability go together in modern democracy. He adds Foucault's (1977, 1978) insight that the creation of normativity was a crucial part of this process. He details the role of the psy disciplines in creating this normative individuality, which supplements Perry's (2018) explication of the ways that ideas of legal personhood and the patriarchal order it helped establish extended from the public to the private sphere. Before the advent of the psy disciplines, Perry (2018) shows, liberalism was establishing practices of surveillance that penetrated intimate relations and assigned people (and nonpeople) their proper places in the system. In turn, Rose (1998) shows how normative and individualizing technologies of democracy and the emerging discipline of psychology worked together as the Enlightenment continued and into the twentieth century, as we will see in more detail below.

As we will see, too, in its current incarnation, neoliberalism, the imbrication of liberal individualism and capitalism within neocolonial globalization, has specific effects on structures and subjectivities. Liberal subjects, formed through the Law and the law-that is, through both symbolic exercises of power and actual juridical decrees and acts-are part of and parceled with modern race and racism, modern gender binaries, modern democracies, industrial and surveillance capitalism, and the idea of the entitled, enabled individual all these constructs need to do their work of domination. These ideas are illustrated in the chapters that follow.

Williams (1991) writes lyrically about the modern implications of the marriage of liberalism and capitalism in the American legal system. She says that individual rights, that concept so dear to America's sense of itself 
and the freedoms on which its righteousness depends, were codified by the law to be available only to those who could afford them. Notions of privacy, of intimacy, and the human connection upon which both rely, she shows, have been corrupted by the power of the marketplace to commodify human value. Perry's (2018) exposition of the initial legal construction of American personhood as dependent on commodities and commodity values, as well as on gender and race, provides the historical and ideological underpinning for the sociolegal dynamics, Williams (1991) identifies.

Williams (1991) writes about the valuation of property as something concrete that can be held to legal standards in contract law, standards which can in theory also protect people. Instead, she says (Williams, 1991), value has come to accrue to the curated meaning of a thing, the associations and desires conjured up by an advertising industry that evades legal accountability by relying on the creation of ephemera and selling the idea it associates with the thing instead of the thing itself.

This language was not available to Williams, but she is talking about the brand. When "masque becomes the basis of our bargains," she says (Williams, 1991, pp. 40-41),

[W] will create new standards of irrelevance in our lives, reordering social relations in favor of the luxurious-and since few of us can afford real luxury, blind greed becomes the necessary companion... Money reflects law and law reflects money, unattached to notions of humanity.

This is also, not coincidentally, an accurate description of how slavery worked. And slavery is surely the institution which most exposes the investments and limits of a system of thought that wants to declare itself for universal human dignity and rights, thus authorizing its own goodness, while also encoding the right to individual profit as part of what it entitles itself to (see Kendi, 2016). The silently raced component of modern liberalism, and its tendency to not know this, is reflected here.

Williams (1991, pp. 71-71) also writes about liberal good intention. She describes a group of white real-estate developers who are considering entering a church in Harlem during an Easter Sunday service to observe the "show" during a walking tour: 
I wondered what would happen if a group of blue-jeaned blacks were to walk uninvited into a synagogue on Passover...- - just to peer, not to pray... Yet the aspect of disrespect, intrusion, seemed irrelevant to this welleducated, affable group of people. They deflected my observation with comments like... "There's no harm intended." As well-intentioned as they were, I was left with the impression that no one existed for them who could not be governed by their intentions.

She adds (Williams, 1991, p. 72), “To live so completely impervious to one's own impact on others is a fragile privilege" — and indeed, fragility is the right frame. It partly explains the defensiveness of well-intentioned white people, in DiAngelo's (2018) term, white fragility. When one's sense of self is based on one's unconscious superiority over the other, wrapped up in one's sense of oneself as therefore obviously a good person, what is at stake when one's intentions are challenged is one's moral goodness. The benefit, the profit accrued from such a positionality of wellintentioned selfhood, for whom the world's goods and meanings are assumed to rightfully exist, is both material and emotional. Both are difficult to give up.

One result is that structures and systems - the law is one of themwhich convey rights on the basis of who can be admitted to the realm of the human (Perry, 2018), continue to mete out standards of inclusion through respectability and recognizability (Butler, 2003). This conflicts with any true accommodation of difference, externally, in terms of social structures, and internally, in terms of psychic relations. Liberalism, despite its stated best intentions to accommodate everyone, encodes normativity. It cannot see equally valuable shared humanity across difference.

\section{A Note on the Idea of the Universally Human}

If there is one thing my career as a professor of Shakespeare studies taught me, it was to be wary of claims to universal humanity. Shakespeare's texts continue to be sold as valuable because of their "universal themes." The very specific material history behind the selection of Shakespeare as the 
embodiment of the best of humanity is necessarily excluded from this messaging. There is concerted colonial education policy, linked to a political agenda of "civilization" and cultural conquest, behind the insistence that England's writer has this kind of moral authority over us all. All good literature, arguably, will make use of universal human themes. But it speaks to structural politics that Chinua Achebe's Things Fall Apart is made to be an African author speaking to local conditions, for example, where Shakespeare's work, equally embedded in local events, becomes "universal" (Distiller, 2004; Dollimore \& Sinfield, 1985; Hawkes, 1992; Holderness, 1988).

The branding of Shakespeare also has an editorial history which is implicated, as all human systems of meaning-making must be, in cultural politics. Just one example is the ways the same-sex eroticism of the sonnets was rewritten by editors, or explained away, while their vicious misogyny was endorsed (Booth, 2000; Duncan Jones, 1997; Fineman, 1986; Halpern, 2002). There is a vast and fascinating academic literature on all these topics: on the construction of Shakespeare's universality via British class and colonial policies; on the editorial history of the works, which helped to invent the idea of the individual genius author out of local writing practices that were much more collaborative and porous; on editorial interpretations and how they built the content for the idea of the universally human; and about how all this played itself out in education systems across the globe during and after high colonialism (e.g., Bristol, 1990; Cloud, 1991; De Grazia, 1991; Distiller, 2009; Erickson, 1991; Howard \& O’Conner, 1987; Joughin, 1997; Loomba, 2002; Marcus, 1996; Taylor, 1989). The political nature of any claim to universality is inescapable to a student of these fields.

And yet the European liberalism that emerged in the Enlightenment believed itself to stand for the best in all of us, with the quiet arrogance of a certain kind of white supremacist Christianity. I have often wondered if it is connected to the Ancient Greeks' arrogance: their designation for their outsiders, "barbarians," meant those who did not have language, and therefore culture, because they did not speak Greek (see Mannarini \& Salvatore, 2020 for a discussion of the entanglement of citizenship and otherness). This assumption of one's own centrality seems to have carried over into many other aspects of the West's sense of itself, 
and been a very valuable tool in justifying the work of colonialism. In the world that colonialism made, a certain use of the language of universal human rights has been deployed by neoliberalism to further entrench global economic systemic inequality (Harvey, 2007).

The idea of some universal humanity that we all share, in other words, has all too often been a tool of power and exploitation. The key question, in the face of the very many differences in cultures that a melting pot theory tends to want to not just wish away, but homogenize into the dominant norm, is: who decides? Whose terms for the apparently universal get to define the idea of the human?

As a result of having been a scholar of English Literature in a postcolony like South Africa, I remain profoundly skeptical of any claims to universality. At the same time, I am arguing for a way to conceptualize something we humans all share, something I am calling complicity. This is my attempt to articulate how, being made in systems of power, as we all are, and having very different and unequal lives as a result, as we do, we nevertheless share a human connectedness. This argument is not the same as a statement of support for a universal humanism.

To be human means to be limited and shaped by the world we have no choice but to enter, the world that makes us. Freud (1973) conceptualized this in terms of the Oedipus complex, where every child must submit to an absolute authority and agree to have his or her (those were his gender options) desire directed by what is socially acceptable. This is another way to theorize the operation of normativity in Western modernity.

After Freud's Oedipus, being a person means having to live with deferred desire. Freud's Oedipus assumes that each subject requires the mother-as-object from which to be forced to separate; the other who can never be had but who is necessary to the self's self-constitution. This is one way to authorize a self/other relation. It depends on treating the (m)other as object (Benjamin, 1988). The child's desire, in this model, is to possess her (Freud understood heterosex to be intrinsically about violent male domination and possession of women, see Distiller, 2011; Freud, 1950; Freud, 1946). But the child's desire is blocked because only the father may have her, in a psychic universalization and justification of what is actually a specific value system: monogamous, heterosexual, 
Judeo-Christian marriage. In this system, human relations are linked to ownership of property, of mothers as property, of children as property and as the conduits of property through inheritance.

The ownership of women's bodies and therefore of female sexuality is a lynchpin of this system (Rubin, 1975; Saini, 2017; Schiebinger, 2004). Because the system is a system of domination in and through which a child of the West must find their subjectivity, the child must learn to accept the loss of the mother who belongs to another, who is the father's. This psychic loss is enforced through the threat of violence, according to Freud: the threat of castration. In Freud's world view, the threat of castration is embodied in the female. She is the sign, for the boy, of what can happen if you do not obey. For the girl, her body, which lacks the signifier of personhood, is something she must come to terms with in order to accept her proper place (Distiller, 2011). While this is not an accurate description of what it invariably is or should meant to be human, to come into subjectivity, it is an excellent description of the gendered rules of our culture, of the patriarchal, capitalist, colonizing Western world Freud assumed was the whole world.

Freud (1950) told us it was human nature to dominate. He said children want to possess their mothers, and that it is only by submitting to the father's prior claim that they could learn their appropriate place. $\mathrm{He}$ said ownership is a foundational element of subjectivity. He told us not only that hierarchy is natural and inevitable, but also that structural power was appropriately male and heterosexual, and implicitly classed and raced through his deployment, throughout his writing, of the figures of "primitives" and the "lower classes" as developmentally akin to children and women. Here is one of the places we see claims to universal meanings reveal their structural embeddedness. So while one answer to the question of why this culture has tended to make the sense it has of difference is, "human nature," I want to continually challenge the politics of that claim. If there is a meaning to "human nature," it is that we are complicit in each other, in all the struggles and power grabs and attempts to cope in this world we have made for ourselves and for each other.

Freud's binary model of subjectivity, which sees the subject as constituted by its difference from the (m)other, enables a liberal politics. This is a politics which facilitated the ideology of imperialism and the practices 
of colonialism, which is built on misogyny and sexism, and which continues to facilitate the violence, hypocrisies and smugness of white supremacism. It is born from and perpetuates the logic of capitalism as survival of the fittest.

There are other options. Dean (2001) suggests that, instead of developing a theory of the subject based on the self's relation to its other, which is a theory which relies on the binary structuring of difference (and, I add, therefore domination) as its starting point, we should start with an acknowledgment of the way otherness structures our internal relations. To see the self as emerging from the self/other relation is to see it as dependent on its difference from an/other in order to know (or construct) itself. But if I see my own internal unknowability, signified by the unconscious, as the condition of my selfhood, then I am in the realm of my own otherness. I also cannot claim to ever know myself, and therefore to be unitary, and must give up all certainties based on this illusory knowledge.

This undermines the authority of the liberal individualistic self. It has a fundamentally different logic to the system of othering on which our current world order depends. This dependence is psychological, economic, political and social. If we recognize that we are always other to ourselves, that the "self" on which the self/other formulation depends is in fact inevitably alienated from itself, we approach a different ethics, Dean (2001) suggests. This way of thinking about otherness-as within the self-also exposes the binary as a construct. Dean's ethics of selfotherness entails granting recognition to the other despite not being able to see what is familiar and knowable in him, her or them (see Glaveanu, 2019). A liberal morality, on the other hand, demands intelligibility before it will confer humanity. It is thus a coercive, normative politics which reproduces its own terms even as it thinks it is making space for an other.

Dean's is a Lacanian perspective which describes human subjectivity as always already split from itself as a condition of its being (directed away from its desire as it is by the Law of the Father; think of Freud's Oedipus). Freud, of course, is the one whose theorizing of the unconscious makes Lacan's split subject possible. In Freud's own terms, we are all constituted from a loss we cannot know: the loss, in Freud's terms, of the mother we 
are never allowed to have because she belongs to the Father. But Freud's terms want to convey security through conveying power. Instead, we could consider the ways we are other to ourselves and see what it takes to tolerate the uncertainty this knowledge brings. It is worth noting that a model of psychology as a science, which tests theories based on measurable outcomes to arrive at objective facts, cannot tolerate this kind of radical uncertainty of meaning.

Making room for what we do not know, for the idea that we might be constituted by things we cannot ever really understand, means we also have to let go of the reflexive defense to find certainty by hardening our identities. The retreat into self-certainty (ego, if you like) always comes, Freud's formulation suggests, at the cost of another's subjectivity. It requires the other as object. (The tragedy of identity politics is that, in making space for the other to take back her personhood, to speak in her own voice and to object to her objectification, it has ended up reproducing the system that it wishes to change. If the position of other becomes a place of certainty, it becomes an identity that requires an oppressor. I say more about this in Chap. 6.)

Glaveanu (2019, p. 454) suggests we start with our own otherness in order to prevent an appropriation of the other in the desire to render her into a "self-like structure":

Starting from the other means recognizing that we are born into a world of others... and that we, ourselves, are other to them. "Being other" is a primary type of human experience with extremely important developmental consequences, particularly if one resists the temptation to destroy the other... or internalize it.

This is a second way to approach otherness in a nonhierarchical manner. We are not only other to ourselves, as Freud's unconscious could have fully taught him if he had not been making meaning from within a binary structure. We are also always others' others. We are complicit in each other's psychic otherness that helps constitute the self, as well as in the material structures and histories that shape subjectivities, and in the discourses that reflect and reproduce these structures and the subjectivities 
they need. If there is anything universally human, it is this always socially, historically and culturally shaped fact.

Blatant racism, sexism, homo- or trans-phobia and classism are not pretending to inclusivity. These isms are clear about their use of the others they create to shore up their sense of selves. Liberalism's good intentions, its denial of the ways it uses the current system to reinscribe itself as the central subject, is what makes it such a frustrating ideology for its progressive opponents. In the effects of its intentions, liberalism is also alike to the notion of human being endorsed by psychology (see Sugarman, 2019).

\section{The Liberal Subject of Psychology}

Rose (1998) argues that Western societies have been freed from religious and political authority only to be enslaved by a liberal individualism enabled by the psy sciences. He (Rose, 1998) details how the techniques of subjectification enabled by the psy disciplines are central to modern subjectivity. Drawing on Foucault (1991), Rose (1998) insists that the modern liberal democratic state cannot be understood as a political formation outside of the regimes of truth about the human subject as citizen that the psy disciplines were central in helping to create. His explanation underscores Brown's (1995), above:

The disciplinization of psychology is constitutively bound to a fundamental transformation that has occurred in the rationalities and technologies of political power since the last decades of the nineteenth century, in which the responsibility of rulers has come to be posed in terms of securing the welfare and normality, physical and mental, of citizens, and of shaping and regulating the ways in which they conduct their 'private' existence-as workers, citizens, fathers, mothers - such that they enact their privacy and freedom according to these norms of maximized normality. The field of power that is codified as the state is intelligible only when located in this wider matrix of projects, programs, and strategies for the conduct of conduct, elaborated and enacted by a whole diversity of authorities shaping and contesting the very boundaries of the political. (Rose, 1998, p. 46) 
What Rose (1998) adds to Brown's (1995) formulation is the role of the psy disciplines as technologies of liberal subjectification in the service of the democratic state. This is what he means when he says, "A psy ontology has come to inhabit us" (Rose, 1998, p. 190. See also Hook 2007).

Foucault (1977) argued something similar when he suggested the panopticon as a metaphor for how a modern regime of power moved from the external imposition of violence as a form of control on the body of the one who transgressed against the ruler, to an internalized, individualized mode of self-control. Modern individuals are formed by self-policing through discourses of normality and deviance that become about who we are as people, what Foucault (2010, p. 145) calls, "the stifling anguish of responsibility... the seals of conscience." This creates an interiority that is made of the psychologized aspect of "self/realization" (Rose, 1998, p. 190), which in turn brings the imperative to freedom: of choice, of political system, of personhood. We liberal Western subjects internalize the rules for who and how to be, and the process of psychotherapy, while it can help to identify and restructure some of these internalized narratives of selfhood, also participates in reiterating the technologies of selfunderstanding which reproduce the creation of the free, autonomous subject who consents to her own subjectification (Butler, 1997).

As we saw in Chap. 1, the subject of psychology is, first and foremost, individualistic. As we have seen in this chapter, this individualism cannot be separated out from Western political structures. Rose (1998) details how, with the help of individual and social psychology, individualism becomes a regulatory device in tandem with the development of modern democratic ideals. Democracy entails commitment to notions of "liberty, equality, and legitimate power" (Rose, 1998, p. 118), in other words, which ensure that a citizenry is ruled by people to whom it conceded control of its own free will. The unified self, while it presents itself as obvious and natural, is instead a socially inscribed production, a construction in time and space and power relations, including economic relations (see Papadopoulos, 2008). I have been suggesting it is dependent on a binary relation of being with otherness which is not only a false message about human being, but one that is responsible for perpetuating systemic oppression. 
Rose (1998) shows how technologies like the scientific definitions and explorations of attitudes, the poll and public opinion were invented in America and enlisted as scientific endorsements of government. Government, in this formulation, is not in fact freely chosen by the people, but is a mode of control that develops from feudal rulers into modern democracies. Following Foucault, from the eighteenth century control of a population entailed, "not just control of a territory and its subjects, but the calculated administration of the life of the population, of each and of all" (Rose, 1998, p. 119). This requires knowing your subjects, who they are and what they want.

It also, as Rose (1998) goes on to show, enables the development of the realization that, just as attitudes can be polled, so they can be affected and changed by communication techniques and the manipulation of messages. This was one locus of Trump's control: the understanding that twenty-first century democratic America, as the culmination of these related technologies of individualization, public opinion and governmentability through discourses of liberty, freedom and choice, runs on the logic not of "the objective characteristics of the situation, but the subjective relation of the individual to his or her situation" (Rose, 1998, p. 130). It is not the facts or the alternative facts that matter, but how a political leader can leverage people's attitudes to the facts.

Talking about liberalism in this way becomes "a series of reflections on government that stress[...] its limits" (Rose, 1998, p. 69). In order for a liberal government to know how much governing of its free citizens is the right amount of intervention into and structuring of private lives, Rose (1998) says, it needed to know its citizens. The psy disciplines were a way to know people so as to know how to govern them (see Foucault, 1978; Foucault, 2010). And as we have seen, this required individualizing human being.

In contradistinction to the production of the liberal, modern, individual self, who knows itself through its responsibility to govern itself according to rules of putative normality, a theory of the subject as complicit suggests that it is never free to be only itself. Such a model undoes the liberal subject at the heart of Western modernity, the center of an invisibly raced, classed and gendered reality. 
These modern inventions also rely on binary thinking. Governmentability relies on the construction of norms. These norms, as we have seen, were produced in tandem with-indeed, helped to produce - the individual liberal subject, free to choose, and apparently therefore self-governing. The requirement for norms against which to measure individual persons required the invention of deviance (Foucault, 1977; Foucault, 1978). The regulatory power of the mythical norm (Lorde, 2007) specifically produces an otherness designed to be exploited. Political, psychic and material gains are all wrapped up in, and reliant on, each other, and in a binary system.

\section{From Liberalism to Neoliberalism}

The taken-for-granted notions which underpin the American dream not only help deny the reality of structural oppression that has in fact built this country. They also have helped, in this great American age where everything, including human connection, is for sale, to commodify identity. This will be discussed in more detail in Chap. 5. In part to pave the way for that discussion, I will now turn to the characteristics of the economic, political and psychic order enabled by the world set in place by Enlightenment-formed liberalism: neoliberalism.

Sugarman (2020) points out that the neoliberal turn of the late twentieth century exacerbated the blind spots of liberalism: by emphasizing the fantasy of free choice while removing governmental responsibility for the social and economic structuring of life, neoliberalism puts the individual even more at risk of being responsible for his own failure, with specific consequences for the psychologization of the subject (see also Melluish, 2014).

Neoliberalism intensifies the atomizing individualism of liberalism, and its relationship to commerce as a naturalized aspect of personhood. It elevates further the celebration of and commitment to freedom of choice, as a personal and an economic imperative. Free market economics and the subject free to choose its participation in this market, together with the advances in technology that lead to social media, created a way to brand identity as and for profit, as we will see in Chap. 5. 
As a political response and an economic system, neoliberalism began in earnest in the 1980s. Neoliberalism is an economic response to a political understanding of human nature and society. It emerged in reaction to the idea of the social welfare state, and to economic stagnation and political threats to liberalism in the 1970 s. It took the terms of liberal individualism - that people should be free to make what choices they want - and applied it to institutional frameworks and the market economy. It sought to remove any constraints that the "embedded liberalism" of the postwar world order built into social, political or economic structures (Harvey, 2007, p. 11; see Chap. 2). It set in place policies intended to deregulate global industry, support a free market economy, encourage competition through privatization, enable flexibility through short-term contracts and worker mobility (and disposability), and discourage the role of government in corporate structures. The market, not the state, should set the terms, neoliberalism says; this will ensure the greatest freedom of choice (Harvey, 2007; Melluish, 2014).

Neoliberalism has been remarkably successful at reshaping social contracts and at reaching into private spheres with the logic of the market. It has reformulated institutions, "divisions of labor, social relations, welfare provisions..., ways of life and thought, reproductive activities, attachments to the land and habits of thought" (Harvey, 2007, p. 3). Along with technological advances, it has intensified, commodified and made ever more literal the use of information about people to help construct subjectivities (see Zuboff, 2019). It has also thus had the consequence of "reformulating personhood, psychological life, moral and ethical responsibility, and what it means to have a selfhood and an identity" (Sugarman, 2020 , p. 74). As the state recedes, "Social control is primarily performed through the colonization of previously regarded private areas of individual experience: the body, health, fashion and well-being, sexuality, your living room" (Papadopoulos, 2008, p. 153; see Davies, 2016). When one of the architects of neoliberalism, Margaret Thatcher, declared that society was to be replaced by individual men and women, she said, "Economics are the method... but the object is to change the soul" (qtd. in Harvey, 2007, p. 23).

Zuboff (2019) argues that this is exactly what has happened. Zuboff (2019) says that neoliberalism broke the social contract liberalism made 
with capitalism. While the postindustrialized Western individual was promised mass-produced access to a goods-based life by what she calls the first modernity, neoliberalism fragmented and atomized connections between people and their institutions, by its hyperindividualizing of commodified desire. The individual of the second modernity is the owner of an iPod, programming their ever-changing unique playlist, rather than the purchaser of a mass-produced CD, released by a music industry that tells us what we like. This second modernity, working together with neoliberalism's dehumanizing "economic violence" (Zuboff, 2019, p. 37), enabled the advent of what she calls surveillance capitalism, where consumer behavior is, first, mined for its commercial value. When the technologies that enable this process are left unchecked, behavior is then manufactured and produced. The industrial revolution that created modern capitalism and its liberal individual entitled to the things capitalism makes has almost cost us our planet, she says. And, she warns, the surveillance capitalism produced by neoliberalism is on the brink of costing us our humanity, as our souls are ever more curated by technology:

Surveillance capitalism operates through unprecedented asymmetries in knowledge and the power that accrues to knowledge. Surveillance capitalists know everything about us, whereas their operations are designed to be unknowable to us. They accumulate vast domains of new knowledge from us, but not for us. They predict our futures for the sake of others' gains, not ours... surveillance capitalism is a rogue force driven by novel economic imperatives that disregard social norms and nullify the elemental rights associated with the individual autonomy that are essential to the very possibility of a democratic society. (Zuboff, 2019, p. 11)

For Zuboff, modernity's necessary creation of liberal individuality, and the democratic state that needs it, is threatened by neoliberalism's enabling of surveillance capitalism. The characteristics of liberalism, especially its moral character, remain for Zuboff the markers of something admirable, necessary and good.

Liberalism created "self-regulating individuals" who, under neoliberalism, have become "networked actors who actively forge the structures necessary" for their atomized modes of regulation (Papadopoulos, 2008, 
p. 153). Liberalism taught us to be individuals with rights that were implicitly linked to ownership, to accumulation, and therefore, I am arguing, in contradistinction to Zuboff's characterization of liberalism, to the exploitation of others. While it may think itself noble, liberalism's intentions do not excuse its impacts. It taught us to take responsibility for ourselves in order to forge compliance with a norm that was used to govern us all. Neoliberalism lifted these values out of the remit of the state and gave them to the deregulated market economy. The result, along with a vastly increased wealth gap, was, "The Commodification of Everything" (Harvey, 2007, p. 165).

One consequence has been the experience, at the level of the individual, of the need to be adaptable and superficial (Cushman, 2019). The self is under immense pressure to constantly consider and reinvent itself in order to stay economically and, for certain classes of Western subjects, socially relevant.

At the same time, neoliberalism intensifies liberalism's problems with otherness. Sugarman (2020) argues that neoliberalism as an ideology of freedom and profiteering discourages the ethical recognition of otherness and difference, and as such is a further technology of ever more toxic, ever more intense individuality. The neoliberal subject, then, is no more able to come to terms with complicity. This is despite its location in networks of connection that are ever more global, and ever more globalized, in world where people and places are, in Melluish's (2014) rephrasing of Giddens (1991), intensely connected, and affect each other across large spatial distances. We will return to this in more detail in Chap. 5.

\section{Complicit Intersubjectivity}

What does a theory of complicity bring to the historical, economic and ethicopolitical processes that have helped to shape the subject of psychology and that psychology has helped to shape? What does it mean to reject the liberal individual in favor of a complicit subject in the therapeutic encounter? The next three chapters will provide details, by exploring both theoretical and practical implications for thinking in a nonbinary way, along specific axes of difference (race, gender and generation). And 
psychotherapy already has a modality that seeks to think about the nonbinary therapeutic use of difference. Other approaches, which may not use these same terms, nevertheless provide ways of practicing that fit within them, as will be explored in Chap. 6 .

Intersubjectivity is a therapeutic approach which understands that binary thinking, based on a way of relating that requires the other to be constituting object for the subject, cannot enable mutual human recognition or connection. Instead, it seeks to name a third, which breaks the binary, and where two subjects can meet as subjects, not pressurizing the other subject into object status. In its classical psychoanalytic definition, it is:

[A] field theory or systems theory... [that] seeks to comprehend psychological phenomena... as forming at the interface of reciprocally interacting subjectivities... It is not the isolated individual mind,... but the larger system created by the mutual interplay between the subjective worlds of patient and analyst... that constitutes the proper domain of... inquiry. (Atwood \& Stolorow, 1993, p. 178)

The suggestion that the analyst is not in objective control of the interaction, is actively participating in what is being made with a client and is fully implicated in all her personhood was unsettling at first to established analytic orthodoxy. There were objections that the approach invited "structureless chaos," "the surrendering of one's personal reality" and "anarchy in the analytic relationship" (Stolorow et al., 1994, pp. 203-208). The challenge to liberal individualism and the illusion of mastery it provides was clearly threatening to the analytical version of the traditional subject of psychology.

The notion of the third undermines the security of the liberal subject, because it requires it to stop using the other's difference to constitute itself. Thinking in terms of the intersubjective third requires a movement into a mutually constituted space where meaning is made in the complex interplay between subjects. This also means by definition that the contexts and systems each subject brings as part of itself must be included as well. If we add a complicit understanding of human being to this approach, we have the potential to meet each other in full recognition of 
our co-constituting influence on each other, structurally (politically, culturally), and interpsychically. We become ourselves because of each other, and it is only in this space that meaning is made, any meaning, but also including therapeutic meaning.

This is what is at stake when we think complicitously as therapists: We are undoing the notion of the individual human we are trying to help. In the process, we also undo our own scientifically-endorsed authority, because this authority is created by and based on the liberal version of the subject it helps to produce. This version of the psy disciplines (authoritative, objective) is a version of the subject that denies complicity. It wants control, boundedness, for the other to be rendered knowable for the sake of the self. As such, it participates in overpowering discursive and material systems of power and inequality, creating, policing and punishing deviance, constructing diagnoses that it passes off as absolute truth in tandem with medical and pharmaceutical industries who go on to profit, underwriting ideas about norms of race, gender and sexuality that have reinforced intersecting oppressions. This is not to suggest that there is no value in seeking patterns or generalizations for diagnostic purpose, or that medication is a conspiracy. But it is to reject the often absolute and objectifying claims made in the name of diagnosis and pharmaceuticals, and to insist that these apparently objectively scientific tools have cultural histories and political implications (some examples include the development of the paraphilias, see Adriaens \& Adriaens \& De Block, 2013; or the understanding and treatment of autism, see Silberman, 2015: gender dysphoria will be addressed in Chap. 4). The complicit therapist's job becomes a question of how to hold containing authority in a nonbinary interpersonal mode.

The achievement of an intersubjective space that is complicit is no simple matter. Complicity suggests shared humanity, and shared responsibility. But equality between participants in an intersubjective therapeutic encounter cannot be wished into being. Indeed, if the therapist cannot acknowledge her structural privilege-according to her social markers, if relevant, and according to her role-then she will fail to know her own complicity in the systems in which both she and her client are subjected. This, too, is taken up in Chap. 6. Knowing, itself, is no easy matter, and 
nor is naming what we might be able to know. Language itself comes burdened with complicity.

In her famous essay of postcolonial theory, "Can the subaltern speak?", Spivak (1988) argued that some of the great poststructuralist theoreticians of the academy (Althusser, Deleuze, Foucault, and Guattari) were guilty of effacing their own social, economic and intellectual power in the process of speaking for and about those who did not have the power to represent themselves, either politically or in the languages of, and cultures formulated by, neocolonial institutions. She said that in the context of concrete power relations, the oppressed (subaltern) subject has no way to speak for herself; the available language cannot be hers. In the context of a binary structure, the subaltern cannot speak in the language given to her by a regulatory system that seeks to both define and control her, as its other.

As I have been suggesting in this chapter, this power dynamic is denied by the very liberalism that constitutes the modern subject, in its inevitably binary formation. And the economic, political, cultural and ideological workings of colonialism are at the start and the center of Western liberal ideals, and underlie the twenty-first century globalized and neoliberal world. While I have also been suggesting that the notion of human being as complicit renders all language problematic if what we want is authentic self-representation (there can be no such thing), Spivak's point reminds us of the necessary both-and of human being in the world today. It is necessary to acknowledge real systems of privilege and inequality that structure people's daily lives as well as their senses of self. And in order to move beyond a social system which uses binary thinking, self/other modes, subject/object power dynamics, enabled by a social symbolic which does the same, we would do well to acknowledge that what makes us all human is our embedded complicity in each other. Postcolonial theory's examinations of cultural hybridities and creolizations help to make this point, that human being is responsive and adaptive and absorptive, even in the face of destructive and oppressive forces (Bhabha, 1994; Distiller, 2005).

Those of us who benefit from privilege, bearing in mind intersectional complexity, are also wounded, if differently, when our constitutive others are hurt so that we may feel whole. For example, there are several 
consequences for white people of living in an oppressive structure even as we benefit from it. Alexander (2012) and Wise (2012) both show how racist impulses in working-class whites served to break possible class alliances and enable the development of economic and social structures that hurt some whites, too. While she wants to make visible the unearned benefits of being in the center of power, MacIntosh (2008) also wants to make the point that "privilege" as a noun for something that confers assets and power at the expense of others is a misnomer. To have this kind of "privilege" is to be morally and psychologically weakened by the unearned advantages we accrue simply by being born. DiAngelo (2018) addresses this white fragility directly, explaining the ways in which whiteness is invisible to most white people, and the consequences of white people's inability to talk about race and the racism in which we white people are all complicit. Humanity suffers when binary thinking is allowed to define our scope of possibilities, an idea which will be expanded upon in more detail in Chap. 4. Allowing this, that human being connects us all, allows us also to share something, even with those whose subjectivity has been rendered other by the systems we share-including therapy.

Swartz (2013) has written about the intersubjective field between white therapist and clients of color in postapartheid South Africa. She says that in the context of historical and ongoing inequality, where racial difference is painful to acknowledge because of all it means in the dyad, naming becomes a very powerful tool:

The challenge is to make a co-constructed intersubjective space, an analytic space in which naming is an occasion for curiosity, and where difference in identity is used not as a final recognition, but as a signal to go beyondtowards a shared humanity. Naming will be a shared, not a unilateral, activity. (Swartz, 2013, p. 20)

This reaching toward mutuality through speaking together, specifically in the recognition of unequal power, counteracts Spivak's subaltern's unspeakable position. It is a reaching toward complicity in human being, where our names for each other become conversations, not labels. In the therapeutic encounter, it is the therapist's responsibility to establish the 
possibility for this space. This is the art of psychotherapy, which cannot be manualized or scientifically measured.

In her case examples, Swartz (2013) spends most time interrogating her own internal fractures and fears as the only way in to engaging with her clients, to take responsibility for the ways in which they could too easily become her constituting other. This work can only occur with the therapist knowing her place in the system, in the encounter, and when privilege has been acknowledged.

Sehrbrock (2020), using intersubjective vocabulary, describes social thirdness, the space made of the collective and the cultural as well as the interpsychic. He describes what happens when what he calls prejudice causes collapse of the social third into the binary: two subjects locked in their own positionality with regard to each other, unable to see the other's point of view. For Sehrbrock, too, in order for the therapist to allow the social third in the intersubjective space, she must be able to tolerate knowledge of her own privilege.

I am aware of how easily this kind of work can recenter whiteness, and other forms of privilege, in the therapeutic encounter. I am also aware of how easily discourses of universal humanity reinscribe the dominant paradigm as the standard for that humanity. However, by locating this work within the intersubjective field, specifically in the analytic third space, Swartz (2013, p. 28) is hoping to use her awareness of her privilege, together with her own intersectionalities, to create a space of true recognition: "Intersubjective theory foregrounds mutual recognition and survival of difference and, paradoxically, in this is contained the possibility of negotiation beyond the dynamic of domination." If we are thinking complicitously, then the survival of difference is more than resisting a dynamic of domination. Difference becomes part of what we share, and the dynamics of domination become a simplified and simplistic reduction of what is possible between us.

Sehrbrock's (2020) examples of working with the social third in therapy are about gender, sexuality, homophobia and misogyny. Swartz's example (Swartz, 2013) is about race. In the next two chapters, I will explore in more detail what a complicit approach - a nonbinary vision, which enables a vision of shared human being-does to race, gender and sexuality as markers of identity, as constructs and as perpetuators of oppression in modern liberal structures which construct and value 
individualism, commodity value and neoliberal performances of personhood. Chapter 5 picks up this last point and focuses on some of the consequences of a subjectivity reliant on social media for younger clients of Western psychotherapy.

Spivak denotes the ability of those in power to define the social/economic/racialized other as epistemic violence. This is the violence made possible by ways of knowing that construct the meanings they go on to find. When a 17-year-old boy can be murdered for walking down the street with a bag of Skittles because of what he is presumed to mean, and when this presumption is endorsed by the jury that found his killer innocent, the epistemic violence at work in American constructions of race and gender is clear to see. In the next chapter, I take seriously the epistemic violence of raced identities in America, while also exploring what a model of complicity has to offer for a way forward.

\section{Works Cited}

Adriaens, P. R., \& De Block, A. (2013). Pathologizing sexual deviance: A history. Journal of Sex Research, 50(3-4), 276-298.

Alexander, M. (2012). The new Jim Crow: Mass incarceration in the age of colorblindness (Rev. ed.). New Press.

Atwood, G. E., \& Stolorow, R. D. (1993). Faces in a cloud: Intersubjectivity in personality theory. Jason Aronson.

Benjamin, J. (1988). The bonds of love: Psychoanalysis, feminism and the problem of domination. Random House.

Bhabha, H. (1994). The location of culture. Routledge.

Biko, S. (1978). I Write What I Like. Ed. A. Stubbs. Bowerdean.

Booth, S. (Ed.). (2000). Shakespeare's sonnets. Yale University Press.

Bristol, M. D. (1990). Shakespeare's America, America's Shakespeare. Routledge.

Brown, W. (1995). States of injury: Power and freedom in late modernity. Princeton University Press.

Butler, J. (1997). The psychic life of power: Theories in subjection. Stanford University Press.

Butler, J. (2003). Precarious life: The powers of mourning and violence. Verso.

Cloud, R. (1991). 'The very names of the Persons': Editing and the invention of dramatick character. In D. S. Kastan \& P. Stallybrass (Eds.), Staging the 
Renaissance: Reinterpretations of Elizabethan and Jacobean drama (pp. 88-96). Routledge.

Cushman, P. (2019). Travels with the self: Interpreting psychology as cultural history. Routledge.

Davies, W. (2016). The happiness industry: How the government and big business sold us well-being. Verso.

Davis, W. (2020). The unravelling of America. Rolling Stone, August 6. Retrieved September 28, 2020, from https:/www.rollingstone.com/politics/politicalcommentary/covid-19-end-of-american-era-wade-davis-1038206/

De Grazia, M. (1991). Shakespeare verbatim: The reproduction of authority and the 1790 apparatus. Clarendon.

Dean, T. (2001). Homosexuality and the problem of otherness. In T. Dean \& C. Lane (Eds.), Homosexuality \& psychoanalysis (pp. 120-146). University of Chicago Press.

DiAngelo, R. (2018). White fragility: Why it's so hard for white people to talk about racism. Beacon.

Distiller, N. (2004). "We're Black, stupid": uMabatha and the new South Africa on the world stage. In N. Distiller \& M. Steyn (Eds.), Under Construction: "Race" and identity in South Africa today (pp. 149-162). Heinemann.

Distiller, N. (2005). South Africa, Shakespeare, and post-colonial culture. Edwin Mellen.

Distiller, N. (2009). Begging the questions: Shakespeare in post-apartheid South Africa. Social Dynamics, 35(1), 177-191.

Distiller, N. (2011). Fixing gender: Lesbian mothers and the Oedipus complex. Farleigh Dickinson University Press.

Dollimore, J., \& Sinfield, A. (Eds.). (1985). Political Shakespeare: New essays in cultural materialism. Manchester University Press.

Duncan Jones, K. (Ed.). (1997). Shakespeare's sonnets. Thomas Nelson.

Erickson, P. (1991). Rewriting Shakespeare, rewriting ourselves. University of California Press.

Fineman, J. (1986). Shakespeare's perjured eye: The invention of poetic subjectivity in the sonnets. University of California Press.

Foucault, M. (1977). Discipline and punish: The birth of the prison. Trans A. Sheridan. Random House.

Foucault, M. (1978). A history of sexuality volume 1. Random House.

Foucault, M. (1991). Governmentality. In G. Burchill, C. Gordon, \& P. Miller (Eds.), The Foucault Effect: Studies in governmental rationality (pp. 16-49). Harvester Wheatsheaf. 
Foucault, M. (2010). The birth of the asylum. In P. Rabinow (Ed.), The Foucault reader (pp. 141-167). Vintage.

Freud, S. (1946). Civilization and its discontents. Hogarth.

Freud, S. (1950). Totem and taboo. Norton.

Freud, S. (1973 [1905]). Three essays on the theory of sexuality. In The standard edition of the complete psychological works of Sigmund Freud, Vol. 7: A case history of hysteria, three essays on sexuality and other works, S. Freud, ed. and Trans. J. Strachey (pp. 125-245). Hogarth Press \& The Institute of Psycho-Analysis.

Giddens, A. (1991). The consequences of modernity. Polity Press.

Glaveanu, V. P. (2019). Being other: Intersubjectivity, allocentrism and the possible. Journal for the Theory of Social Behaviour, 49(4), 443-459.

Guyatt, N. (2016). Bind us apart: How enlightened Americans invented racial segregation. Basic.

Halpern, R. (2002). Shakespeare's perfume: Sodomy and sublimity in The Sonnets, Wilde, Freud, and Lacan. University of Pennsylvania Press.

Harvey, D. (2007). A brief history of neoliberalism. Oxford University Press.

Hawkes, T. (1992). Meaning by Shakespeare. Routledge.

Holderness, G. (Ed.). (1988). The Shakespeare myth. Manchester University Press. Hook, D. (2007). Foucault, psychology and the analytics of power. New York: Palgrave Macmillan.

Howard, J. E., \& O'Conner, M. F. (Eds.). (1987). Shakespeare reproduced: The text in history and ideology. Methuen.

Husemeyer, L. (Ed.). (1997). Watchdogs or hypocrites? The amazing debate on South African liberals and liberalism. Friedrich-Naumann-Stiftung.

Johnson, R. W., \& Welsh, D. (Eds.). (1998). Ironic victory: Liberalism in postliberation South Africa. Oxford University Press.

Joughin, J. (Ed.). (1997). Shakespeare and national culture. Manchester University Press.

Kendi, I. X. (2016). Stamped from the beginning: The definitive history of racist ideas in America. Bold Type Books.

Loomba, A. (2002). Shakespeare, race, and colonialism. Oxford University Press. Lorde, A. (2007). Sister outsider: Essays and speeches. Crossing.

MacIntosh, P. (2008). White privilege and male privilege: A personal account of coming to see correspondences through work in Women's Studies. In M. McGoldrick \& K. V. Hardy (Eds.), Re-visioning family therapy: Race, culture, and gender in clinical practice (pp. 238-249). Guilford. 
Mannarini, T., \& Salvatore, S. (2020). The politicization of otherness and the privatization of the enemy: Cultural hinderances and assets for active citizenship. Human Affairs, 30, 86-95.

Marcus, L. (1996). Unediting the renaissance: Shakespeare, Marlowe, Milton. Routledge.

Mehta, U. S. (1999). Liberalism and empire: A study in nineteenth-century British liberal thought. University of Chicago Press.

Melluish, S. (2014). Globalization, culture and psychology. International Review of Psychiatry, 26(5), 538-543.

Papadopoulos, D. (2008). In the ruins of representation: Identity, individuality, subjectification. British Journal of Social Psychology, 47, 139-165.

Perry, I. (2018). Vexy thing: On gender and liberation. Duke University Press.

Rich, P. B. (1997). A new South African liberal conscience? Current Writing, 9(2), 1-20.

Rose, N. (1998). Inventing our selves: Psychology, power, and personhood. Cambridge University Press.

Rubin, G. (1975). The Traffic in Women: Notes on the "Political Economy" of Sex. In R. R. Reiter (Ed.), Toward an anthropology of women (pp. 157-210). Monthly Review.

Saini, A. (2017). Inferior: How science got women wrong - And the new research that's rewriting the story. Beacon.

Schiebinger, L. (2004). Nature's body: Gender in the making of modern science. Rutgers University Press.

Sehrbrock, J. (2020). Social thirdness: Intersubjective conceptions of the experience of gender prejudice. Psychoanalysis, Self and Context, 15(3), 289-295.

Silberman, S. (2015). Neuro Tribes: The legacy of autism and the future of neurodiversity. Penguin.

Spivak, G. (1988). Can the subaltern speak? In C. Nelson \& L. Grossberg (Eds.), Marxism and the interpretation of culture (pp. 271-313). Macmillan.

Stolorow, R. D., Atwood, G. E., \& Brandchaft, B. (Eds.). (1994). The intersubjective perspective. Jason Aronson.

Sugarman, J. (2019). An historical turn for theoretical and philosophical psychology. In T. Teo (Ed.), Re-envisioning theoretical psychology: Diverging ideas and practices (pp. 25-48). Springer.

Sugarman,J.(2020). Neoliberalismand theethicsofpsychology.InD.M.Goodman, E. R. Severson, \& H. Macdonald (Eds.), Race, rage, and resistance: Philosophy, psychology, and the perils of individualism (pp. 73-89). Routledge. 
Swartz, S. (2013). Naming and otherness: South African intersubjective psychoanalytic psychotherapy and the negotiation of racialised histories. In C. Smith, G. Lobban, \& M. O'Loughlin (Eds.), Psychodynamic psychotherapy in South Africa (pp. 13-10). Wits University Press.

Taylor, G. (1989). Reinventing Shakespeare: A cultural history from the Restoration to the present. Oxford University Press.

Williams, P. (1991). The Alchemy of race and rights. Harvard University Press. Wise, T. (2012). Dear White America: Letter to a new minority. City Lights. Zuboff, S. (2019). The age of surveillance capitalism: The fight for a human future at the new frontier of power. Profile.

Open Access This chapter is licensed under the terms of the Creative Commons Attribution 4.0 International License (http://creativecommons.org/licenses/ by/4.0/), which permits use, sharing, adaptation, distribution and reproduction in any medium or format, as long as you give appropriate credit to the original author(s) and the source, provide a link to the Creative Commons licence and indicate if changes were made.

The images or other third party material in this chapter are included in the chapter's Creative Commons licence, unless indicated otherwise in a credit line to the material. If material is not included in the chapter's Creative Commons licence and your intended use is not permitted by statutory regulation or exceeds the permitted use, you will need to obtain permission directly from the copyright holder.

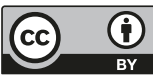

